\title{
石屋製菓の商品開発と北海道の食素材
}

鴨川靖司

（石屋製菓株式会社 商品開発室シェフパティシエ）

\section{Product development of office Ishiya Co.,Ltd. and food materials in Hokkaido}

\author{
Yasushi Kamogawa
}

Ishiya Co.,Ltd., 2-10-30, 2jo, Miyanosawa, Nishi-ku, Sapporo-shi, Hokkaido, 063-0052

テ063-0052＼cjkstart北海道札幌市西区宮の沢 2 条 2 丁目10-30

\section{1．石屋製菓の歴史と挑戦}

1947年に現社長の祖父・石水幸安がでんぷん工場を札 幌で創業し，1959年には石屋製菓株式会社を10名規模で 設立しました。「白い恋人」に代表される北海道の食材 を活かした商品により全国的知名度が得られ，創業70周 年を迎えた今年（2017年） 4 月には東京銀座 6 丁目の GINZA SIX に北海道初の常設店舗「ISHIYA GINZA」(図 1) を出店し，伸長する売上に対応するため，7月には 最新鋭の北広島工場（北海道北広島市）(図 2 ) を稼働 するに至りました。

石屋は常に北海道を意識して商品を開発してきました。 ラングドシャーを筒状に巻いた「北海道バ夕ー巻」に始 まり,サブレの「銭函」を世に出し,さらに1976年発売 の「白い恋人」(図 3 ) はネーミング, 品質, 広告宣伝 が連携して代表的な北海道の土産菓子として広く知られ るようになりました。ちなみに「白い恋人」の名付け親 は創業者の石水幸安です。家族とスキーに行った折，降
り出した雪を見て、「白い恋人たちが降ってきたよ」の 一言が由来となっています。今ではライン生産の「白い 恋人」ですが，当初は焼き上げた熱いラングドシャーを 手で挟むという大変な作業で作られていました。製造方 法の工夫は消費者の需要に応える上では久かせません。 消費者にアピールできる商品を作るためには，企業理念 でもある「しあわせをつくる拈菓子」をもとに，新しい 菓子を作り出すチームと, 営業, 販売, 製造, 広告宣伝 など会社全体が協働することが必要です。このチーム ワークによって良い商品が生まれていきます。

消費者への接点としてのタッチポイント／コンタクト ポイントも大切です。北海道新幹線開業（2016年 3 月, 新青森駅一新函館北斗駅) 時の広告と, サッカーチーム のコンサドーレが J 1 に昇格した2017年の開幕戦の広告 がそれぞれ「広告電通賞」と「北海道知事賞」を受賞し， 好評を得ました。さらに GINZA SIX オープン時の新聞 広告では当社の新たな戦略を示しました。図 4 の右が北 海道版で,「白い恋人は北海道外の常設店では販売しま
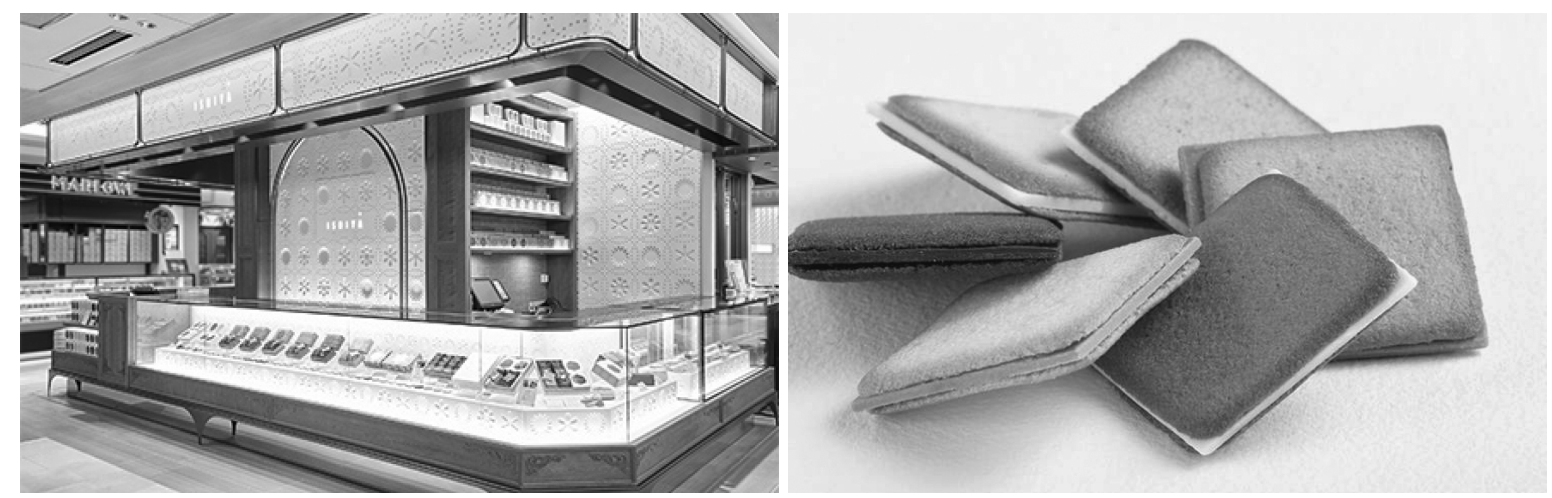

図 1 ISHIYA GINZA と北海道外限定販売商品（右） 

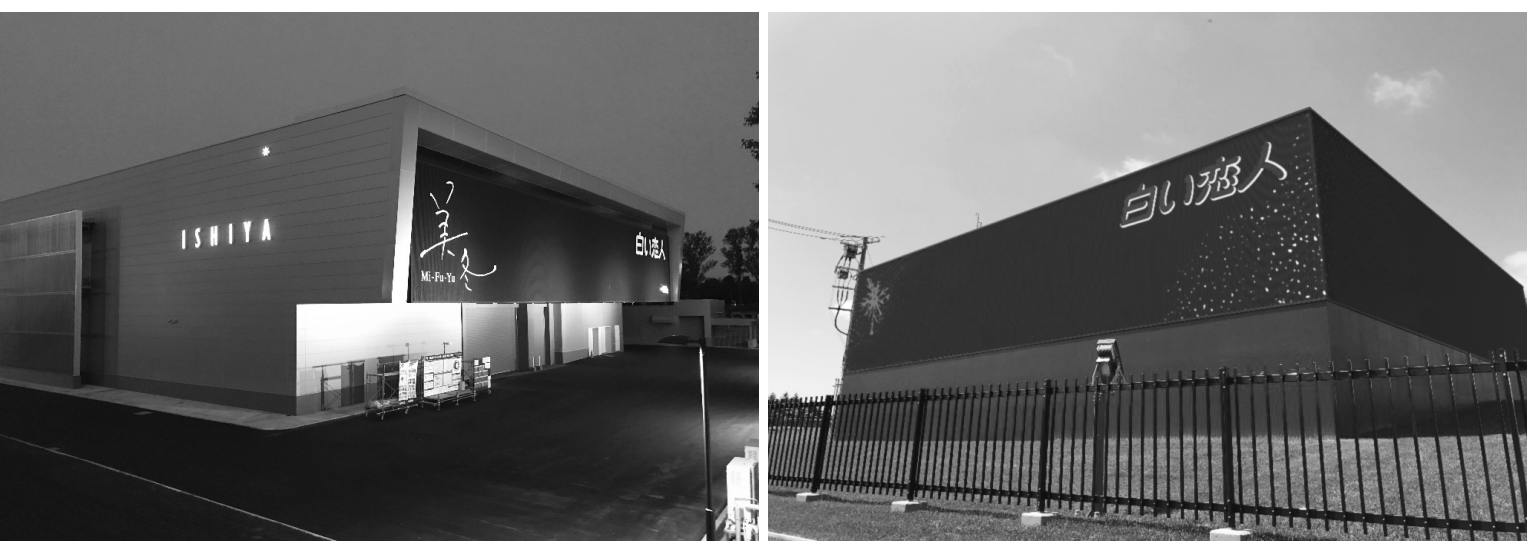

図 2 石屋製菓北広島工場

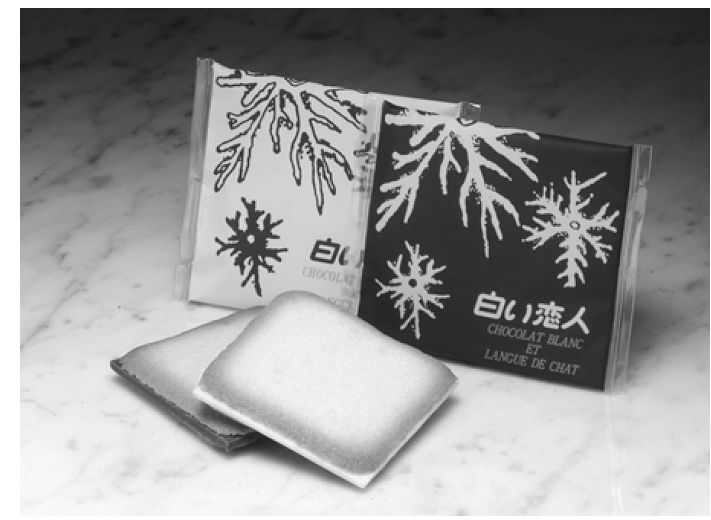

図 3 「白い恋人」

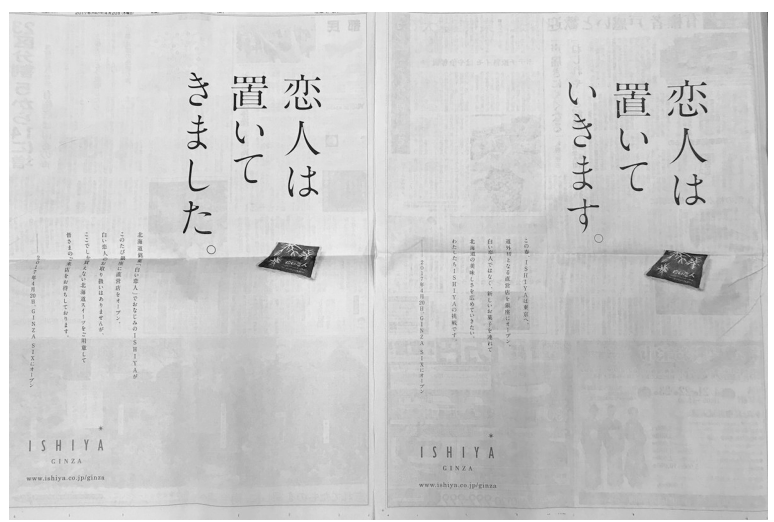

図 4 ISHIYA GINZA の広告（左：関東版, 右 : 北海道版）

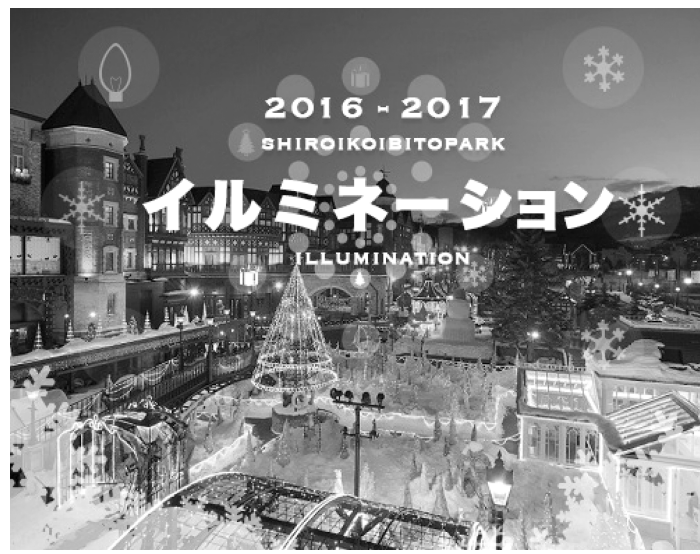

図 5 白い恋人パーク (http://www.shiroikoibitopark.jp/)
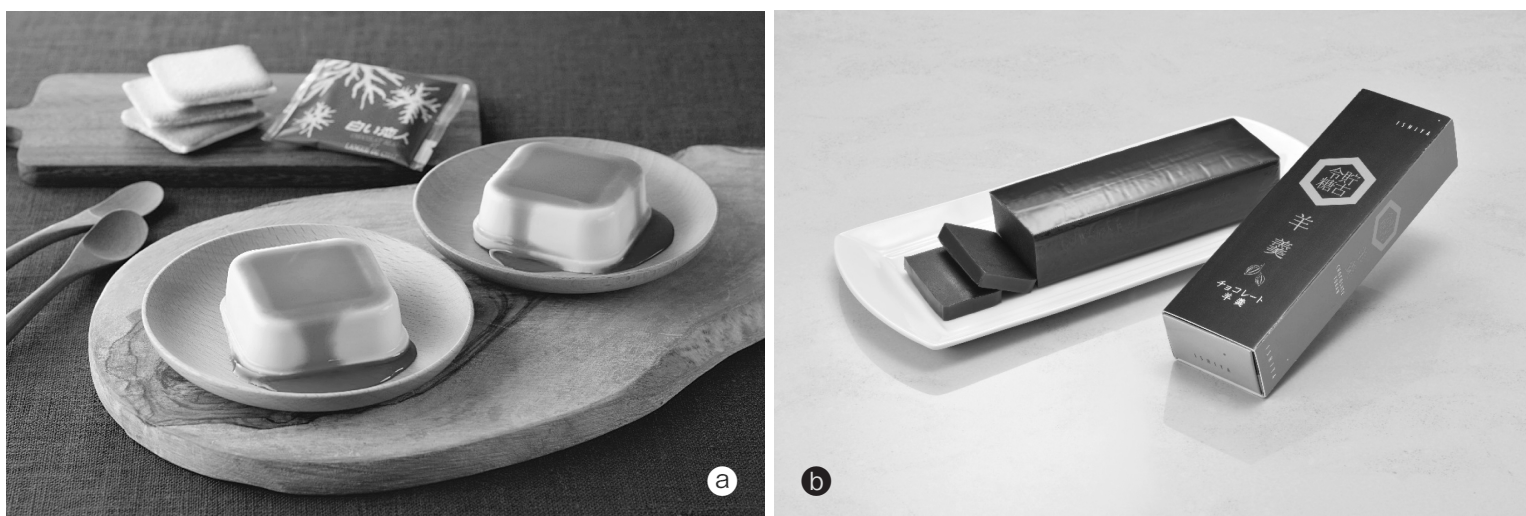

図 6 北海道の食素材を活かした商品 


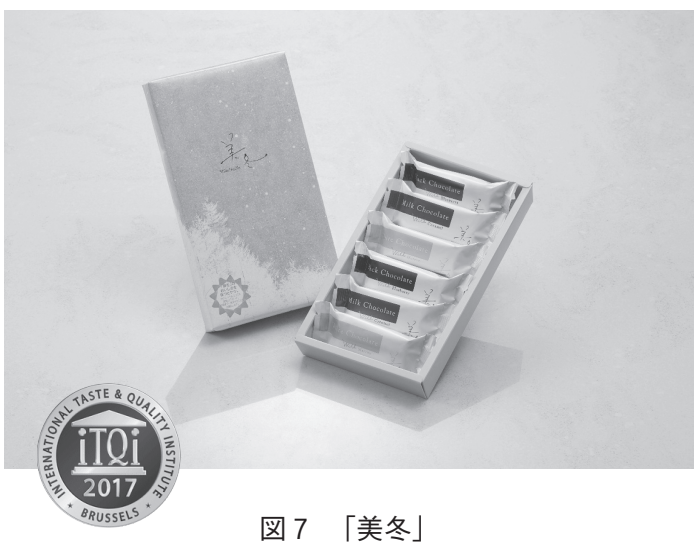

(iTQi 優秀味覚賞（2 つ星）受賞）

せん」という方針を表しています。左が関東版で，「新 しいイシヤ銀座の商品を日本の代表的な土産菓子にす る」という決意が込められています。広告のほかには, 各地の北海道物産展やインターネットの利用も㧍客様と の大事な接点となっています。消費者と直接交流できる 「白い恋人パーク」では冬のシーズンの新たな拄客様を 獲得するため, 約11万個の電球が煌びやかに彩り, 空に は約250体の雪だるまが打客様を打出迎えし幻想的な雾 囲気に包まれています（図 5 )。さらなる楽しさを目指 しリニューアルも進行中です。

\section{2. 北海道の食素材を活かす}

北海道は良質の食素材の宝庫です。良質の素材からは 美味しい製品が生まれます。北海道産の乳製品と小麦粉 と卵をべースに「白い恋人」のラングドシャーができ， その「白い恋人」のホワイトチョコレートを練り込んだ プリンが生まれ（図 $6 \mathrm{a}$ ），それには北海道産のハスカッ プソースが添えられています。十勝産小豆 $100 \%$ の羊美 をチョコレートに練り込んだ「チョコレート羊羍」(図 6 b）もあります。「ISHIYA GINZA」では「白い恋人」 のコンセプトを受け継いだ商品や，富良野メロン，サロ マ湖産の塩，北海道はちみつを使用した商品などを販売 して，北海道の食材の良さをアピールしています。
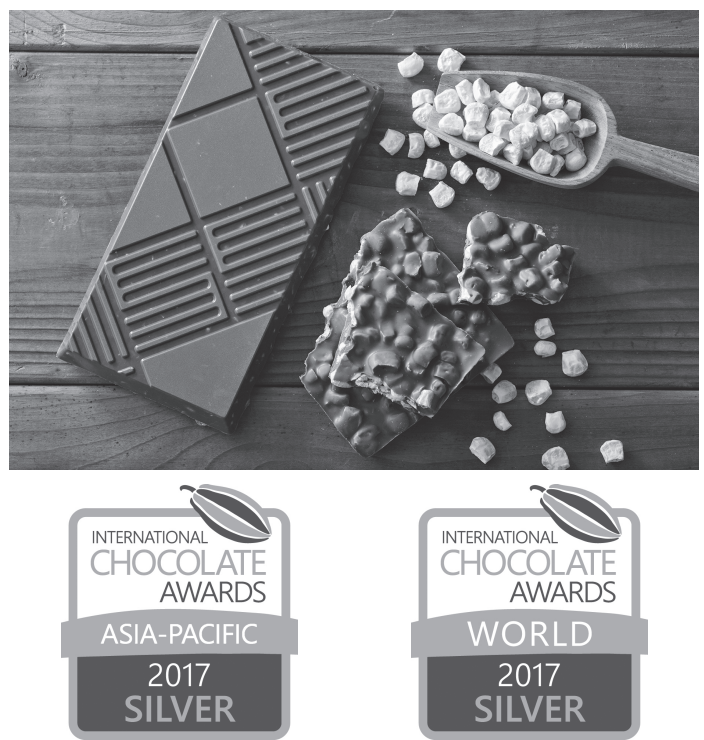

図 8 「とうきび」

(ICAアメリカ\&アジア太平洋大会銀賞受賞, ICA 世界大会銀賞受賞)

\section{3. 北海道から日本へ，そして世界へ}

北海道内限定発売の㧍土産菓子「白い恋人」から， $\lceil$ ISHIYA GINZA」に打ける北海道外限定販売ギフト . 手土産商品への拡充へと歩みを進めてきました。さらに， 主力商品の冬美は iTQi（国際味覚審査機構）による「美 味しさ」認定審査を受け，新しい柱として本格進出をし たチョコレートでは，ICA（インターナショナル・チョ コレート・アワード）といった世界的コンクールにも出 品して，世界が認めた品質のアピールを目指しています。 2017年出品の「美冬」(図 7 ) と「とうきび」(図 8 ) は 世界品質として高い評価を受け受賞しており，今後の販 売への展開に期待がふくらみます。製品を通して日本と 北海道の食素材の素晴らしさを世界に知っていただくこ とを願い、これからも全社一丸となり価值ある商品を開 発してまいります。

本稿は，「北海道の食」をテーマとした第55回大会講演をまとめたものである。 